\title{
(2) OPEN ACCESS \\ Promoting independent living and preventing lonely death in an older adult: Soma Idobata-Nagaya after the 2011 Fukushima disaster
}

\author{
Naomi Ito, ${ }^{1}$ Yuri Kinoshita, ${ }^{2,3}$ Tomohiro Morita, ${ }^{4}$ Masaharu Tsubokura ${ }^{1}$
}

\begin{abstract}
'Department of Radiation Health Management, Fukushima Medical University, Fukushima, Japan

${ }^{2}$ Department of Public Health, Fukushima Medical University, Fukushima, Japan ${ }^{3}$ Division of Food Science and Nutrition, Tohoku Seikatsu Bunka Junior College, Sendai, Mlyagi, Japan

${ }^{4}$ Department of Internal Medicine, Soma Central Hospital, Soma, Japan
\end{abstract}

Correspondence to Naomi Ito; itonaomi@fmu.ac.jp

Accepted 21 January 2022

\section{Check for updates}

(C) BMJ Publishing Group Limited 2022. Re-use permitted under CC BY-NC. No commercial re-use. See rights and permissions. Published by BMJ.

To cite: Ito N, Kinoshita $Y$ Morita T, et al. BMJ Case Rep 2022:15:e243117. doi:10.1136/bcr-2021243117

\section{SUMMARY}

Contrary to the assumption that older adults are only cared for by their families in rural Japan, this case illustrates that community formation can effectively provide older adult care after an emergency as well. We look at the life of a woman who lived in a housing facility for older adults, Idobata-Nagaya in Soma, Japan, exploring how social housing - which addresses the needs of older adults regarding community, familiarity and socialising — can provide a viable, effective and comfortable environment for older adults to live. In the case of Idobata-Nagaya, not only could older adults take care of one another but they could also share experiences of the Fukushima disaster with each other. This is a qualitative case study which provides a stable foundation for policymakers, healthcare workers and government officials to better understand the effectiveness of housing projects for communities and older adults in Japan and globally.

\section{BACKGROUND}

Most people, regardless of their age, desire to live in a familiar place. ${ }^{1-3}$ By living in a familiar town, older adults gain a sense of independence, dignity and improved quality of life. Although disasters or illnesses can impact living arrangements, 'aging in place' is an important public health goal among older adults. ${ }^{4}$ Aging in place is the concept of living independently in a familiar community until the end of one's life.

Many older adults desire to live independently in a familiar area. However, until recently, it was conventionally believed that older adults needed support from their immediate families to live independently. Meanwhile, communities based on blood ties have weakened, and alternative types of support are being explored. ${ }^{5}$ Lonely death is a Japanese phenomenon which refers to individuals being left unattended for a considerable period after their death. Recently, it has become inevitable for older adults to live alone. We believe that efforts to reduce isolated deaths will shorten the postmortem discovery time. Therefore, we advocate for the social participation of older adults after retirement and active visits by caregivers. ${ }^{6}$

In Europe and the USA, there are living set-ups called cohousing and collective housing where individuals can live together. In Japan, the introduction of apartment housing in response to the frequent occurrence of lonely deaths in temporary housing after the Great Hanshin earthquake has been found to be effective. ${ }^{78}$ In Japan, there is a strong attachment to families and homes, and the concept of aging in place has been introduced in comprehensive community support as a preparation for a superageing society. ${ }^{9}$ Along with housing developments, such as serviced elderly housing, community-based services have also been promoted. ${ }^{10}$

Social isolation and lonely deaths are critical problems, particularly in areas that have been hit by natural disasters. ${ }^{11}$ In 2011, the Great East Japan Earthquake caused massive tsunami damage in Soma, a city of 37000 people, located $45 \mathrm{~km}$ north of the Fukushima Daiichi Nuclear Power Plant. Many residents lost their homes, and families were forced to relocate to temporary housing. Moreover, the city has been experiencing a decline in the ageing population over the years. In 2020, people aged 65 years and over accounted for only $31.0 \%$ of the population. ${ }^{12}$ The city placed a high priority on reconstructing the lives of its residents. Therefore, the Soma Idobata-Nagaya (rowhouse, in Japanese) was built to serve as a form of public housing to meet the needs of independent older adults and individuals with disabilities. ${ }^{13}$ The housing project intended to meet the wish of its residents to live in a familiar place while receiving mutual support and to promote mental and physical healing after the disaster (figure 1).

Moreover, research on efforts to achieve aging in place in an area affected by a natural disaster is scarce. Additionally, the type and amount of care an older adult receives in a medical emergency in similar housing projects have not been investigated. This report is a qualitative study that describes a woman in her 80s, living independently in a familiar community rowhouse with residents she had known before. She made the choice of living alone rather than with her family after the tsunami disaster. In the end, she passed away because of an acute illness while being cared for by friends and neighbours. This report demonstrates that longterm, intimate care for older adults can be effective in a post-disaster housing community.

\section{CASE PRESENTATION}

A woman in her 80s lived near the coast of Soma city. She lived with her husband, her eldest son and his wife. The tsunami engulfed her house during the March 2011 earthquake; however, she was able to escape in her son's car. Though the house remained, the mud carried by the tsunami flooded her house. She sought shelter in an evacuation centre, then 


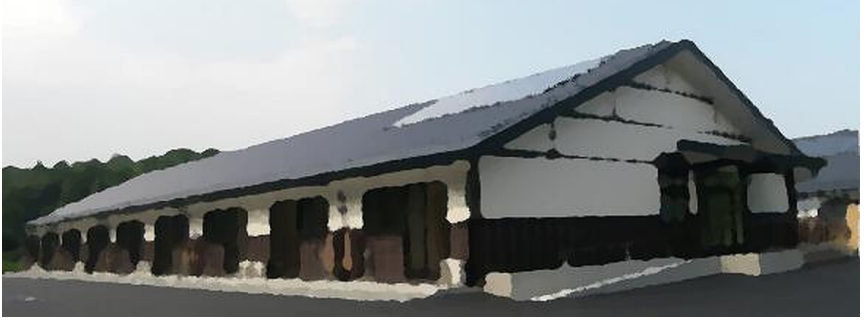

Figure 1 Front view of Idobata-Nagaya. The building style is known as Nagaya, a rowhouse commonly inhabited by ordinary people in downtown areas during the Edo period. This drawing was drawn by NI.

moved into temporary housing and eventually relocated to an apartment in Soma city. She and her husband decided to live separately from their son due to space issues. In July 2012, while she was living in the new apartment, her husband died of lung cancer, leaving her alone. A year later, in June 2013, she moved to a Nagaya. Over the corresponding period of 2 years and 3 months after leaving her original house, she had lived in four separate residences.

Initially, after her husband's death, her son invited her to live with him and his wife in their new house. However, she decided to live alone as she did not have a good relationship with her daughter-in-law. Her son and his wife occasionally escorted her to doctor's appointments but were usually not on good terms with her. Their visits were limited to emergencies, and her calls to them were mostly unanswered. She told other residents that she envied those whose children and grandchildren visited them frequently.

Although she was independent in her daily activities, the woman did not want to live alone; she did not want to live in a nursing care facility either. She was invited to sign up for the rowhouse by a friend from her dance circle. At the rowhouse, she engaged with residents who came from the same town as her. Subsequently, she built close friendships with her nextdoor neighbours. She even got to know one of her neighbour's parents, shared dishes and assisted her rowhouse neighbours when they had problems. She participated in morning exercise routines organised for the rowhouse residents. She believed that participation in community events was crucial, and she always kept her door open as a sign of welcome.

However, she suddenly developed an aortic dissection while living at Nagaya and died at the hospital on the same day. Her neighbour, a long-term friend, cared for her until her last day. For several months before she died, she occasionally complained about her health problems to her neighbours. Her neighbour would care for her and contact her son, who lived far away, on her behalf. One morning, she experienced vomiting and diarrhoea and speed-dialled her neighbour to ask for help; again, the same neighbour contacted her family and sent her to an emergency room. She relied on her neighbours for survival; she would not have been able to receive prompt hospital care without assistance from her neighbours.

According to 30 interviews, this woman represents a typical case of Nagaya where older adults were able to avoid lonely deaths due to community support. This case report was based on multiple sources of information (interviews and observations) in order to capture real-life social phenomena and to enhance the internal validity of the study. ${ }^{14}$

\section{GLOBAL HEALTH PROBLEM LIST}

- Although there is an increase in lonely deaths globally, measures against lonely deaths are critical in areas where disasters have led to ageing in isolation.

- Connections with people in the local community rather than biological families may support older adults living alone.

- An environment where people can share their disaster experiences may help them recover psychologically.

- Considering aging in place in areas where communities have collapsed due to disasters is an important issue in public health.

\section{GLOBAL HEALTH PROBLEM ANALYSIS}

The construction of housing complexes for older adults after the earthquake in Soma helped the city build a strong social capital. Such complexes had built-in mutual assistance and monitoring functions for older adults, services that had traditionally been provided by their immediate family members. This case exemplifies that, through community support, we can successfully prevent older adults from living isolated lives and experiencing lonely deaths.

Toward the end of her life, the woman's long-term friends who were living in the same area played more critical roles than her biological family. She may have been happy passing away without bothering her family and we, as healthcare workers, were able to fully respond to her wishes. She wanted to live alone, yet did not want to feel lonely, and did not want to engage with her family.

Some older adults need connections with people who come from the same town, rather than their own family. Government officials have recognised this preference after several meetings with local residents. Therefore, it has been decided that public housing structures needed to be built near their original community to ensure communal homogeneity among residents. Various government programmes related to Nagaya were enacted to support independent living for older adults, ${ }^{15} 16$ such as low rent, manager supervision, free bus outings and free lunch distribution. Specifically, Nagaya residents are covered by a post-disaster rent reduction project, which costs between $\$ 30$ and $\$ 100$ per month. Everyday the residents shared stories about their homes and families and their lands that were washed away by the tsunami. A case report indicated that residents of Nagaya who shared their experiences of the tsunami damage showed improved recovery from PTSD. ${ }^{17}$ The same effects may not have been attained in nursing home facilities.

During this research, it became clear that many older adults started a new phase of life by choosing to live in rowhouses with long-term friends and neighbours, rather than their own families. Today, with an ageing society, declining birth rates and structural changes in family, building human connections is becoming increasingly challenging. The rowhouse project and its operations helped people realise a new phase of life based on the philosophy of aging in place.

This case report aims to inform policy, practice and research in older adult care, both domestically and internationally. Future research could broadly explore the effects of rowhouse projects in urban and rural areas, areas unaffected by natural disasters, in older adults of different age groups and diverse socioeconomic and medical conditions.

Contributors $\mathrm{NI}$ conceived the study and drafted the article. YK, TM and MT participated in the study design and helped with coordination and editing. All the 


\section{Patient's perspective}

People in the rowhouse still often talk about this woman who suddenly passed away. The neighbour of this woman, who was her friend, became depressed after the woman's unexpected death. Notably, after sharing her experience with the other neighbours, she felt validated by them and gained an acknowledgement of her feelings. After her death, one of her friends from the rowhouse said, 'I feel lonely; it is as if I've lost my own family'; another neighbour commented, 'I wish I could die without bothering my family as she did' and one remembered her fondly and said, 'I want to live as fully as she did'.

\section{Learning points}

- Some older adults might prefer connections with people who come from the same town, rather than their own family.

- The rowhouse community had built-in mutual assistance and monitoring functions to help older adults live independently.

- Rowhouses offer older people a friendly and familiar environment that they may not experience in nursing home facilities.

authors were involved in the conception and design of the study, interpretation of the case and final approval of the article.

Funding This work was supported by Research Project on the Health Effects of Radiation organised by Ministry of the Environment, Japan.

Competing interests None declared.

Patient consent for publication Consent obtained from parent(s)/guardian(s). Provenance and peer review Not commissioned; externally peer reviewed.

Open access This is an open access article distributed in accordance with the Creative Commons Attribution Non Commercial (CC BY-NC 4.0) license, which permits others to distribute, remix, adapt, build upon this work non-commercially, and license their derivative works on different terms, provided the original work is properly cited and the use is non-commercial. See: http://creativecommons.org/ licenses/by-nc/4.0/.
Case reports provide a valuable learning resource for the scientific community and can indicate areas of interest for future research. They should not be used in isolation to guide treatment choices or public health policy.

\section{REFERENCES}

1 Kelen J, Griffiths KA. Housing for the aged: new roles for social work. Int J Aging Hum Dev 1983;16:125-33.

2 Sykes JT. Living independently with neighbors who care: strategies to facilitate aging in place. In: Aging in place: supporting the frail elderly in residential environments, 1990: 53-74.

3 Ball MM, Perkins MM, Whittington FJ, et al. Managing decline in assisted living: the key to aging in place. J Gerontol B Psychol Sci Soc Sci 2004;59:S202-12.

4 Shih RA, Acosta JD, Chen EK, et al. Improving disaster resilience among older adults: insights from public health departments and Aging-in-Place efforts. Rand Health Q 2018;8:3.

5 Murayama $\mathrm{Y}$, Murayama $\mathrm{H}$, Hasebe $\mathrm{M}$, et al. The impact of intergenerational programs on social capital in Japan: a randomized population-based cross-sectional study. BMC Public Health 2019;19:156.

6 Morita S, Nishi K, Furukawa F, et al. A survey of solitary deaths in Japan for shortening postmortem interval until discover. Pril 2015;36:47-51.

7 Vestbro DU. From collective housing to cohousing - a summary of research. J Archit Plann Res 2000:164-78.

8 Cotterell N, Buffel T, Phillipson C. Preventing social isolation in older people. Maturitas 2018;113:80-4.

9 Song P, Tang W. The community-based integrated care system in Japan: health care and nursing care challenges posed by super-aged Society. Biosci Trends 2019;13:279-81.

10 Nagata C, Tsutsumi M, Kiyonaga A, et al. Evaluation of a training program for community-based end-of-life care of older people toward aging in place: a mixed methods study. Nurse Educ Pract 2021;54:103091.

11 Kako M, Ikeda S. Volunteer experiences in community housing during the great Hanshin-Awaji earthquake, Japan. Nurs Health Sci 2009;11:357-9.

12 Ishikawa K, Kanazawa Y, Morimoto S, et al. Depopulation with rapid aging in Minamisoma City after the Fukushima Daiichi nuclear power plant accident. J Am Geriatr Soc 2012;60:2357-8

13 Yoshida I, Morita T, Ishii T, et al. Minimizing isolation of the elderly following the Fukushima nuclear power plant disaster. Disaster Med Public Health Prep 2020:1-3.

14 Crowe S, Cresswell K, Robertson A, et al. The case study approach. BMC Med Res Methodol 2011:11:100.

15 Pirrie M, Harrison L, Angeles R, et al. Poverty and food insecurity of older adults living in social housing in Ontario: a cross-sectional study. BMC Public Health 2020;20:1320.

16 Mattos MK, Burke LE, Baernholdt M, et al. Perceived social determinants of health among older, Rural-Dwelling adults with early-stage cognitive impairment. Dementia 2019;18:920-35.

17 Hori A, Morita T, Yoshida I, et al. Enhancement of PTSD treatment through social support in Idobata-Nagaya community housing after Fukushima's triple disaster. BMJ Case Rep 2018;2018. doi:10.1136/bcr-2018-224935. [Epub ahead of print: 19 Jun 2018].

Copyright 2022 BMJ Publishing Group. All rights reserved. For permission to reuse any of this content visit

https://www.bmj.com/company/products-services/rights-and-licensing/permissions/

BMJ Case Report Fellows may re-use this article for personal use and teaching without any further permission.

Become a Fellow of BMJ Case Reports today and you can:

- Submit as many cases as you like

Enjoy fast sympathetic peer review and rapid publication of accepted articles

- Access all the published articles

Re-use any of the published material for personal use and teaching without further permission

Customer Service

If you have any further queries about your subscription, please contact our customer services team on +44 (0) 2071111105 or via email at support@bmj.com.

Visit casereports.bmj.com for more articles like this and to become a Fellow 